\title{
Quantitative assessment of the impact of ecological energy sources on atmospheric pollution
}

\author{
Michat Stefaniuk ${ }^{1}$, Patrycja Libirt ${ }^{1}$, Beata Migas ${ }^{1}$ \\ ${ }^{1}$ AGH University of Science and Technology, Faculty of Geology, Geophysics and Environmental \\ Protection, Department of Fossil Fuels, A. Mickiewicza 30 Ave, 30-059 Krakow, Poland
}

\begin{abstract}
Environmental pollution, in particular atmospheric pollution, is largely associated with the production of thermal energy. Suspended dusts and chemically aggressive gases generate a significant danger for as well human health as biosphere. In recent years there has been a growing conviction about decisive impact of greenhouse gasses emission generated by the economic and civilizational activity of humanity on global climate changes. Hopes of breaking these adverse trends is connected with the mass use of renewable energy sources or rather so called ecological energy sources, that are relatively less environmentally aggressive. The quantitative comparative assessment of their negative impact on the environment is important in the proper classification of energy sources. Comparing of quantities of emitted suspended dusts and aggressive gases including greenhouse gases is good parameter for evaluation of air pollution. In Polish conditions, atmospheric pollutions are predominated by products of coal combustion. A good indicator of the ecological quality of energy sources is therefore the reduction of emitted harmful substances as a result of coal substitution. In this work examples of ecological effects of geothermal installations have been presented. Geothermal energy is generally considered to be renewable and ecological, while the substitution of coal fuels by hydrocarbons, including natural gas, is more problematic. The comparative analysis performed for a single-family house shows a radical reduction in the emission of suspended dust and chemically aggressive gases associated with replacing the coal furnace by natural gasfired boiler and reducing the emission of carbon dioxide by half.
\end{abstract}

Keywords: atmospheric pollution, geothermal energy, natural gas, coal, ecological effect.

\section{Introduction}

Environmental pollution, in particular atmospheric pollution, is largely associated with the production of thermal energy. Suspended dusts and chemically aggressive gases generate a significant danger for as well human health as biosphere. In recent years there has been a growing conviction about decisive impact of greenhouse gasses emission generated by the economic and civilizational activity of humanity on global climate 
changes, in particular on the so-called global warming. Hopes of breaking these adverse trends is connected with the mass use of renewable energy sources. From the point of view of negative influence on environment, it seems more effective to use the so called ecological energy sources, that are relatively less environmentally aggressive. The quantitative comparative assessment of their negative impact on the environment is important in the proper classification of energy sources. Comparing of quantities of emitted suspended dusts and aggressive gases dangerous for human health and ecosystems, including greenhouse gases is good parameter for evaluation of air pollution. In Polish conditions, atmospheric pollutions are predominated by products of coal combustion, mainly hard coal. A good indicator of the ecological quality of energy sources is therefore the reduction of emitted harmful substances as a result of coal substitution. Comparative studies are difficult due to lack of systematic observations of the level of emitted pollutions, especially for hard coal combustion. In this situation, it is possible to use emission limit standards for the analyzed fuels, treating them as the estimated minimum values. In this work examples of ecological effects of geothermal installations have been presented. Geothermal energy is generally considered to be renewable and ecological, while the substitution of coal fuels by hydrocarbons, including natural gas, is more problematic. The comparative analysis performed for a single-family house shows a radical reduction in the emission of suspended dust and chemically aggressive gases associated with replacing the coal furnace by natural gas-fired boiler and reducing the emission of carbon dioxide by half. From the point of view of local pollutions, this substitution is therefore justified. However, its positive impact on global climate processes is less obvious.

\section{Evaluation of ecological effect of geothermal heating installation.}

According to definition geothermal energy is non-anthropogenic energy cumulated as heat below earth surface in results of geological or radiogenic processes, independently from depth of occurrence [1]. Development of geothermal energetics in Poland is important part of energy policy of the State establishing increase of use of renewable energy sources up to $15 \%$ of final gross energy consumption in 2020 year. The use of this type of energy could not solve energetic problems of the country, nevertheless geothermic could play important role in local scale. Potentially favorable geological conditions for geothermal water occurrence in Poland occur in the area of over 250 thousand $\mathrm{km}^{2}$. In this area covering jointly one third surface of the Country, thermal water of temperature $20-100{ }^{\circ} \mathrm{C}$ could be obtained from depth range 1-3 km. Regions with optimal geothermal conditions frequently coincide with areas of intensive agriculture as well as urbanized areas of cities and villages. Such situation creates possibility of versatile (cascade type) use of geothermal energy in wide range of temperatures [2]. As example of such solution could be Geotermia Uniejów Company that supply heat as well for private and public utility buildings heating as balneotherapy and recreation and sport venues [3]. The Uniejów town is located in the area of mogileńsko-łódzkie synclinorium in central part of Polish Lowlands (Fig. 1). Resources of geothermal waters in this area are connected with Lower Cretaceous formation of thickness about $120 \mathrm{~m}$. The reservoir is developed in fractured and porous sandstone measures buried to the depth range of $2000 \mathrm{~m}$. The temperature of the water at the outflow of the boreholes reaches $70^{\circ} \mathrm{C}$, productivity under conditions of self-flow is about $70 \mathrm{~m}^{3} / \mathrm{h}$. These are chloride-sodium waters containing fluorine and boron with $6,8-$ 
$8,8 \mathrm{~g} / \mathrm{dm}^{3}$ mineralization. The influence of contemporary atmospheric factors is small, despite this reservoir is recently supplied with infiltrating waters [4].

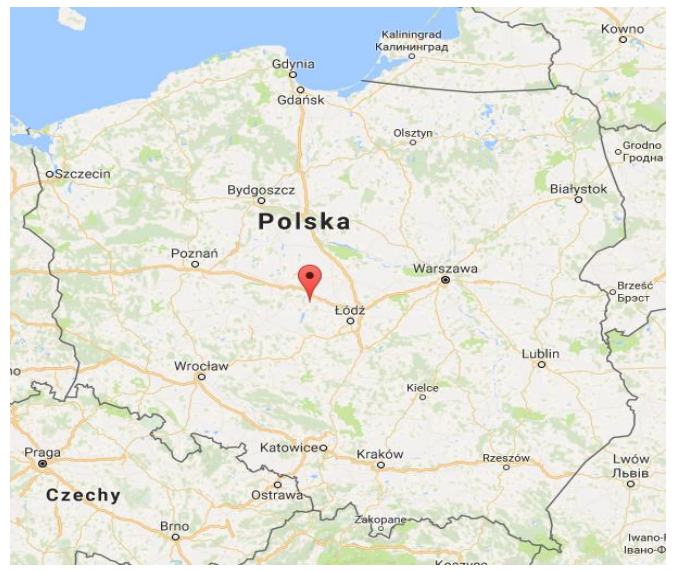

Fig. 1. Location of Uniejów at the map of Poland [5].

Geothermal heating plant in Uniejow is characterised by power that is sourced from the system of receiving heat from thermal water, which equals to 3,2 $\mathrm{MW}$ and provides in heat about 2000 inhabitants, buildings of public utility and sport venues. Three geothermal wells are used in the heating system of Uniejow: stand-by inserting borehole $2254 \mathrm{~m}$ deep, inserting borehole $2065 \mathrm{~m}$ deep and exploitation borehole $2031 \mathrm{~m}$ deep. Exploitation of thermal waters and recovery of the heat contained in them takes place in a closed cycle (Fig. 2). In this system hot water is extracted from exploitation well and after passing through the filtration system, it is pumped to heat exchangers. After putting heat in the exchangers, water is directed to the inserting wells and then to the aquifer. The supplement

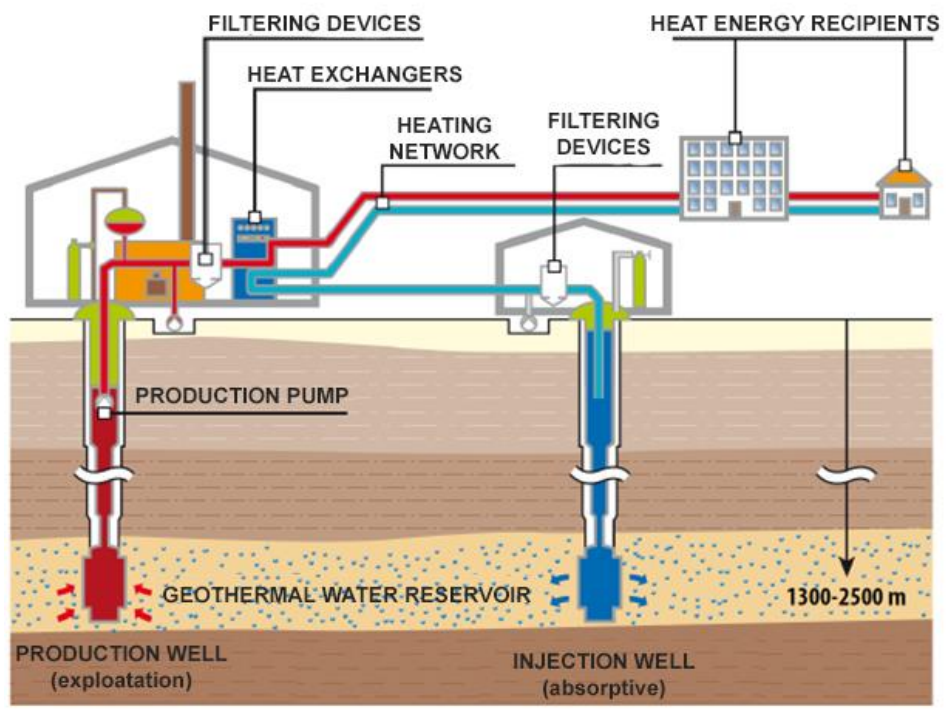

Fig. 2. The outline of the heating installation in Uniejow [6]. 
to the geothermal system, activated at an outdoor temperature below $-5^{\circ} \mathrm{C}$, there are two wood chips boilers with a total capacity of 1,8 MW and oil "peak" boilers with a total capacity of 2,4 MW. In the presented work there were calculated real ecological benefits of investment, that are results of replacement conventional wood and coal-fired stoves by geothermal energy. The ecological effect, so-called avoided emission, was calculated based on the methodology proposed by the National Center for Balancing and Management of Emissions (KOBIZE- in Polish-Krajowy Ośrodek Bilansowania i Zarzadzania Emisjami). The data obtained from the plant „Geotermia Uniejów”, concerning the sale of thermal energy in particular months of 2016 year made it possible to calculate total geothermal energy production per year. The heating values (WO) and $\mathrm{CO}_{2}$ emission index (WE) shared by KOBIZE for the 2016 year, allowed to calculate the amount of hard coal that should be burned in order to obtain the amount of heat produced by the "Geotermia Uniejów" plant in that year and evaluate amount of $\mathrm{CO}_{2}$ emissions per year [7]. The quantity of pollutants avoided, such as suspended dusts PM10 and PM2,5, benzo(a)pyrene, nitrogen oxides $\mathrm{NO}_{\mathrm{x}}$ and sulfur oxides $\mathrm{SO}_{2}$, were also calculated [3]. Those emissions were calculated as effect of working of hypothetical, conventional coal-fired heat plant, that would possess power corresponding to Geotermia Uniejow power 3,2 MW. The calculated values are presented in tabular form (Tab.1.).

\begin{tabular}{|c|c|c|}
\hline Analized parameter & Modeled quantity & Unit \\
\hline Coal amount & 1031,11 & $\mathrm{t}$ \\
\hline $\mathrm{CO}_{2}$ & 2063,97 & $\mathrm{~g}$ \\
\hline PM10 & 1672300,25 & $\mathrm{~g}$ \\
\hline PM2.5 & 1584284,44 & $\mathrm{~g}$ \\
\hline Benzo(a)pyrene & 286,05 & $\mathrm{~g}$ \\
\hline SO $_{2}$ & 19803555,54 & $\mathrm{~g}$ \\
\hline NO & 3960711,11 & \\
\hline $\mathrm{x}$ & & $\mathrm{g}$ \\
\hline
\end{tabular}

Tab.1. The estimated amount of pollution emitted to the atmosphere as a results of burning of coal in a hypothetical coal-fired heating plant with the power of ,Geotermia Uniejów" heat plant, during year. 


\section{Comparison study of atmospheric pollutions between coal and natural gas used for heating of isolated house.}

The basic source of local atmospheric pollutions is so called low emission mainly connected with residential buildings heating. The choose of fuel is important for the cost of house heating and type and quantity of pollutants emitted to the atmosphere. The fuel that is most frequently used for one-family houses heating in Poland is hard coal. The heating values (WO) and amount of contained sulfur and ash that decide of its energetic value and quantity of emitted pollutants are the base of hard coal classification. The another popular fuel used to heating purposes is natural gas. The analysis of ecological effect of substitution of coal by natural gas used to heat a detached house with the total useful floor area of $175 \mathrm{~m}^{2}$ and the heating demand amounting $100 \mathrm{kWh} / \mathrm{m}^{2} /$ year was made [8]. Two boilers used for combustion of hard coal and natural gas were selected for comparison calculations. The request for heat was evaluated on $17500 \mathrm{kWh} /$ year $(63000 \mathrm{MJ} /$ year $)$. Taking into account heating values of compared fuels and selected boilers efficiencies, the use of fuels per year were evaluated. Then, the amount of pollutants emissions such as carbon dioxide $\mathrm{CO}_{2}$, carbon monoxide $\mathrm{CO}$, suspended dusts PM10 and PM2,5, benzo(a)pyrene, nitrogen oxides $\mathrm{NO}_{\mathrm{x}}$ and sulfur oxides $\mathrm{SO}_{2}$ per year for both fuels were calculated basing of the emission indicators taken from KOBIZE data base [8]. Comparative emission levels of pollutants are listed in table number 2 .

\begin{tabular}{|l|c|c|c|}
\hline Pollutants & $\begin{array}{c}\text { Emissions as a } \\
\text { result of coal } \\
\text { combustion [kg] }\end{array}$ & $\begin{array}{l}\text { Emissions as a } \\
\text { result of natural gas } \\
\text { combustion [kg] }\end{array}$ & $\begin{array}{c}\text { Avoided } \\
\text { emissions [kg] }\end{array}$ \\
\hline $\begin{array}{l}\text { Sulfur oxides (SOx, } \\
\text { SO2) }\end{array}$ & 51,20 & 0,06 & 51,14 (853) \\
\hline $\begin{array}{l}\text { Nitrogen oxides (NOx, } \\
\text { NO2) }\end{array}$ & 7,04 & 2,28 & $4,76(3.1)$ \\
\hline $\begin{array}{l}\text { Carbon monoxide (CO) } \\
\text { Carbon dioxide (CO2) }\end{array}$ & 144,00 & 0,45 & $143,55(320)$ \\
\hline $\begin{array}{l}\text { Suspended dust, total } \\
\text { (TSP) }\end{array}$ & 5900 & 3000 & $2920(1.96)$ \\
\hline \\
benzo(a)pyrene
\end{tabular}

Tab. 2. Avoided emission as result of substitution of hard coal by natural gas in single-family house heating - multiple reductions in red in brackets. 


\section{Conclusions}

The construction of the geothermal heat plant radically reduced the amount of dust and gas pollutions released into the atmosphere in the area of Uniejów. Potential pollutants emitted by the plant may come only from the combustion of fuel oil and wood chips in the peak boiler room, which is to assist geothermal energy in time of low outside temperatures. Replacement of hard coal by natural gas in heating a single-family house will cause a radical reduction in the emission volume from the analyzed pollutants. Replacing the fuel type will result in a decrease in carbon monoxide emissions by over $99 \%$ and a reduction in emissions of sulfur oxides and particulate matter to negligible amounts. In the case of nitrogen oxides, a reduction of almost $70 \%$ will be possible. Carbon dioxide emissions will also be reduced by around 50\%. When natural gas is used, no benzo (a) pyrene is emitted. The substitution of hard coal by natural gas radically reduces emissions of locally harmful substances, and also reduces by half greenhouse gas emissions that stimulate the so-called global warming.

Acknowledgements. The paper was prepared in the framework of statutory research of Department of Fossil Fuels, contract no.: 11.11.140.031.

\section{References}

1. Bujakowski W., 2015: Geologiczne, środowiskowe i techniczne uwarunkowania projektowania i funkcjonowania zakładów geotermalnych w Polsce. Polska Akademia Nauk, Instytut Gospodarki Surowcami Mineralnymi i Energią, Kraków.

2. Górecki W. (red.) i in., 2006: Atlas zasobów geotermalnych formacji mezozoicznej na Niżu Polskim. Ministerstwo Środowiska, Narodowy Fundusz Środowiska i Gospodarki Wodnej, Akademia Górniczo-Hutnicza, Państwowy Instytut Geologiczny, Kraków.

3. Migas B. 2018 Ecological Aspects of the Use of Geothermal Energy on the Basis of Geothermal Heating Plant in Uniejów. Engineering Project. (in Polish).

4. Sapińska-Śliwa A., 2009: Technologiczne $i$ ekonomiczne zagadnienia zagospodarowania wody termalnej na przyktadzie Uniejowa. Rozprawa doktorska.

5. Mapy Google, www.google.pl/maps, 2017.

6. Kurpik J., 2017, Efektywność energetyczna, ekonomiczna i ekologiczna instalacji geotermalnych $w$ Polsce, doświadczenia eksploatacyjne, Materiały konferencyjne $\mathrm{z}$ konferencji „Geotermia Impulsem Rozwoju Polskiej Gospodarki”, Warszawa.

7. KOBIZE - Krajowy Ośrodek Bilansowania i Zarządzania Emisjami, 2017Wartości opałowe (WO) i wskaźniki emisji $\mathrm{CO}_{2}$ (WE) w roku 2013 do raportowania w ramach Systemu Handlu Uprawnieniami do Emisji za rok 2016: http://www.kobize.pl/.

8. Libirt P., 2019 Evaluation of the Ecological Effect of Replacing Coal by Natural Gas in Heating a Detached House. Engineering Project. (in Polish). 